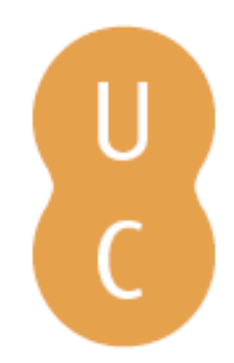

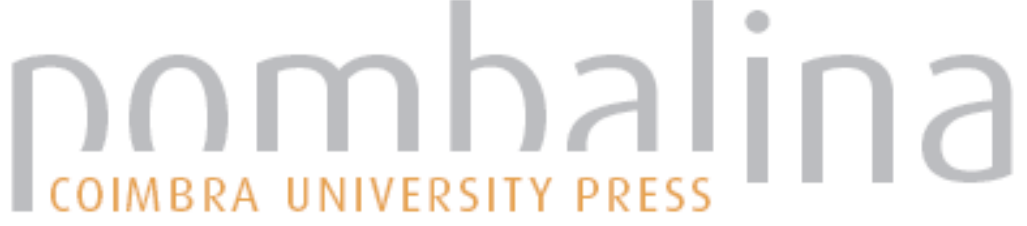

\section{Simmel: a estética e a cidade}

\author{
Autor(es): $\quad$ Simmel, Georg \\ Publicado por: Imprensa da Universidade de Coimbra \\ URL \\ persistente: URI:http://hdl.handle.net/10316.2/2616 \\ DOI: $\quad$ DOI:http://dx.doi.org/10.14195/978-989-26-0207-3
}

Accessed : $\quad$ 22-May-2017 14:02:29

A navegação consulta e descarregamento dos títulos inseridos nas Bibliotecas Digitais UC Digitalis, UC Pombalina e UC Impactum, pressupõem a aceitação plena e sem reservas dos Termos e Condições de Uso destas Bibliotecas Digitais, disponíveis em https://digitalis.uc.pt/pt-pt/termos.

Conforme exposto nos referidos Termos e Condições de Uso, o descarregamento de títulos de acesso restrito requer uma licença válida de autorização devendo o utilizador aceder ao(s) documento(s) a partir de um endereço de IP da instituição detentora da supramencionada licença.

Ao utilizador é apenas permitido o descarregamento para uso pessoal, pelo que o emprego do(s) título(s) descarregado(s) para outro fim, designadamente comercial, carece de autorização do respetivo autor ou editor da obra.

Na medida em que todas as obras da UC Digitalis se encontram protegidas pelo Código do Direito de Autor e Direitos Conexos e demais legislação aplicável, toda a cópia, parcial ou total, deste documento, nos casos em que é legalmente admitida, deverá conter ou fazer-se acompanhar por este aviso.






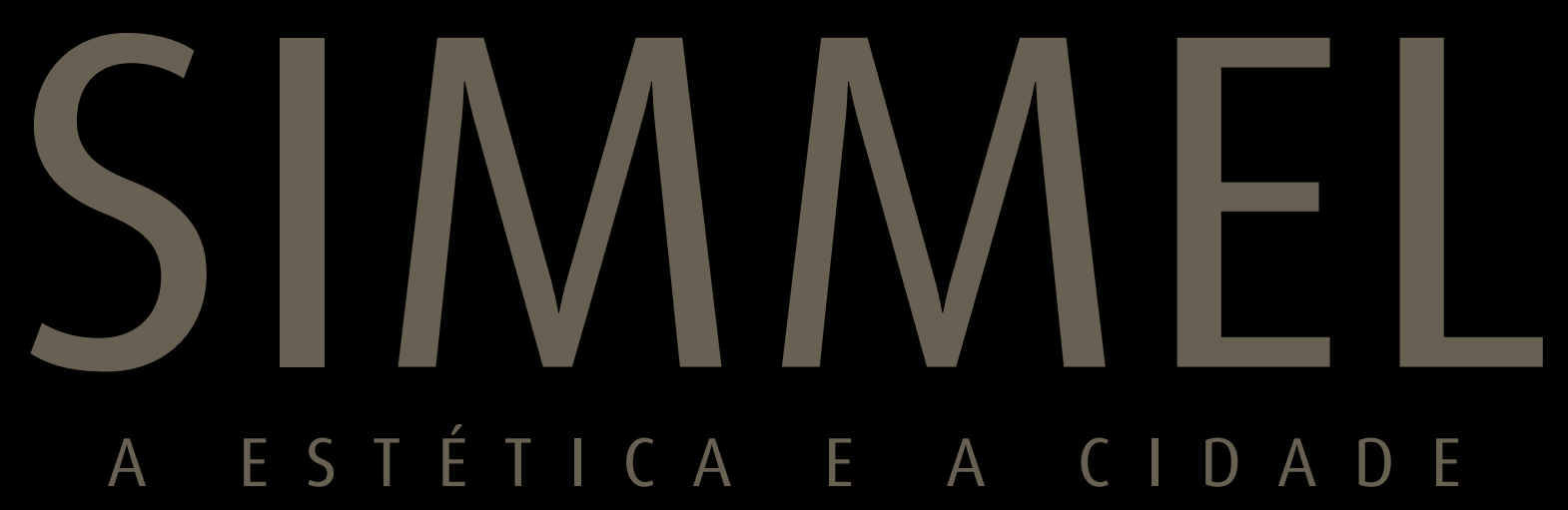

ORGANIZAÇÃO E INTRODUÇÃO

CARLOS FORTUNA 
(Página deixada propositadamente em branco) 


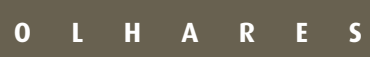


(Página deixada propositadamente em branco) 


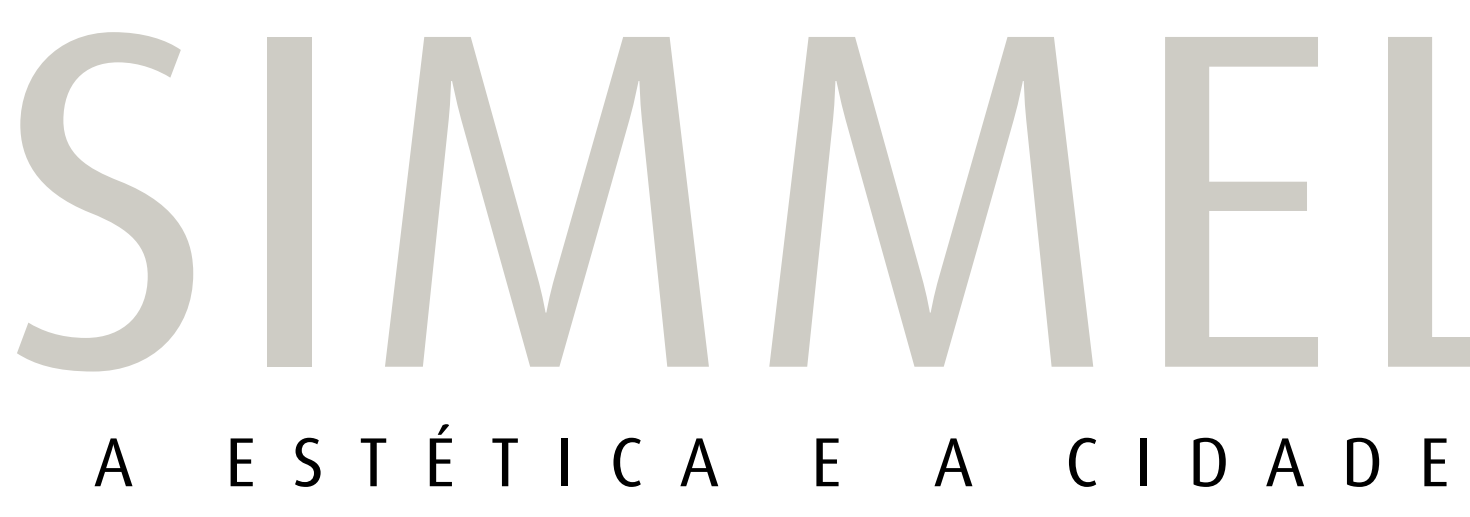

ORGANIZAÇÃO E INTRODUÇÃO

CARLOS FORTUNA 
COORDENAÇÃo EDITORIAL

Imprensa da Universidade de Coimbra

Email: imprensauc@ci.uc.pt

URL: http://www.uc.pt/imprensa_uc

Vendas online: http://www.livrariadaimprensa.com

CONCEPÇÃO GRÁFICA

António Barros

INFOGRAFIA

Carlos Costa

Imprensa da Universidade de Coimbra

EXECUÇÃO GRÁFICA

Gráfica de Coimbra

ISBN

978-989-26-0062-8

ISBN DIGITAL

978-989-26-0207-3

DOI

http://dx.doi.org/10.14195/978-989-26-0207-3

Depósito LEgAL

313808/10

(c) Julho 2010, Imprensa da Universidade de Coimbra 
GEORG SIMMEL

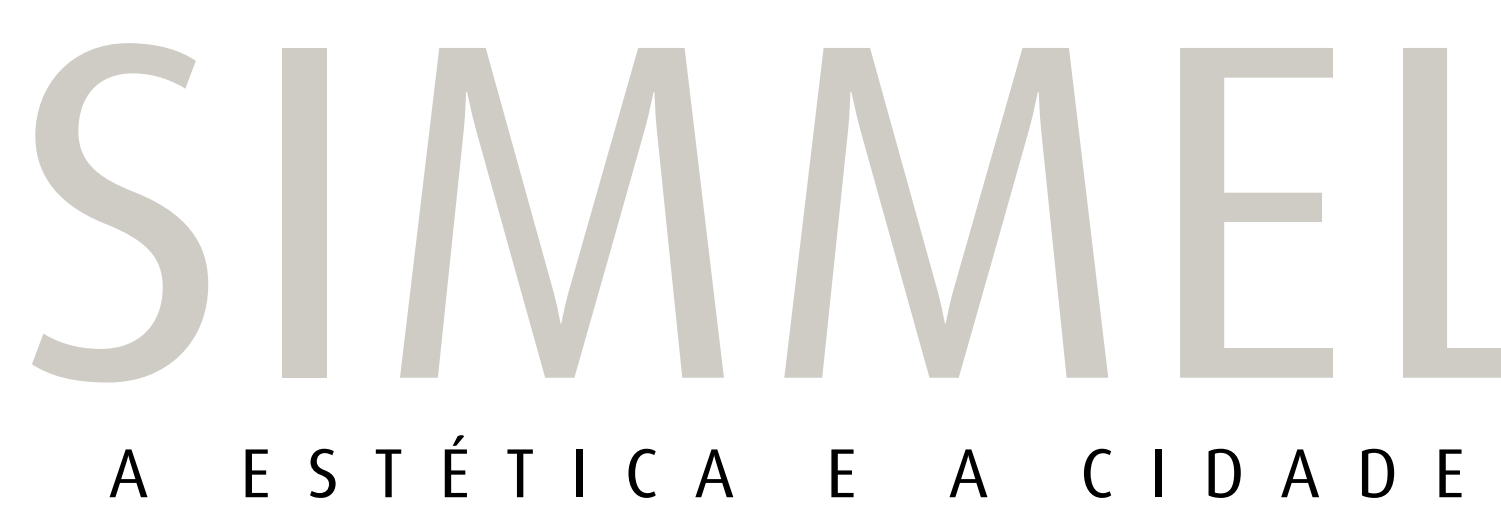

ORGANIZAÇÃO E INTRODUÇÃO

CARLOS FORTUNA

TRADUÇÂO

ANTÓNIO SOUSA RIBEIRO 

SUMÁRIO

CARLOS FORTUNA

Simmel e as cidades históricas italianas

Uma introdução 9

GEORG SIMMEL

Roma. Uma análise estética

19

Florença 31

Veneza 39 

SIMMEL E AS CIDADES HISTÓRICAS ITALIANAS - UMA INTRODUÇÃO 
(Página deixada propositadamente em branco) 
Os três ensaios de Georg Simmel que a seguir se publicam, dedicados a três cidades históricas italianas, são preciosas reflexões filosóficas e sociológicas sobre a arte, a estética e a sua relação com a cidade. Trata-se de um conjunto de temas caros a Simmel, aliás já enunciados na sua dissertação sobre a filosofia kantiana em 1881, sobre os quais, como se sabe, o autor haveria de continuar a reflectir até ao final da sua vida em 1918.

No momento, quando se multiplicam as acções e as reflexões sobre a história, a memória e os patrimónios da humanidade e se redobra a preocupação com as dimensões estéticas e culturais das cidades, estes textos centenários de Simmel ganham relevo redobrado. São, a vários títulos, textos pioneiros.

Desde logo porque, ao surgirem num momento de intensa transformação política e cultural na Europa, obrigaram a reconsiderar os termos da reflexão política e académica sobre a relação indivíduo-sociedade, ao chamar a atenção para a articulação da arte e da estética com o espírito e a vida da cidade. No domínio das ciências sociais e humanas, o contributo de Simmel perdurou e teve impacto nos trabalhos de ilustres pensadores e analistas. Nomes consagrados e tão variados como os de John Ruskin, Aloïs Riegl, David Lowenthal ou Françoise Choay, mas também Walter Benjamin ou Siegfried Kracauer, são alguns dos intelectuais e estudiosos que, cada um a seu modo, também eles se depararam com preocupações em todo semelhantes às reveladas nestes textos de Simmel, ou actualizaram mesmo a reflexão sobre o lugar da estética, da arquitectura e da organização e usos dos espaços da cidade na construção da modernidade.

O carácter pioneiro destes textos decorre ainda da alternativa que constituiram face à literatura de viagem, tal como esta se desenvolvera nos primórdios do século XVIII, isto é, olhando as cidades e as outras culturas de forma fundamentalmente descritiva, impessoal e centrada no relato de factores pitorescos (Boyer, 1998). No decurso do século XIX, a narrativa de viagem ganhou contornos mais imaginativos e os seus autores passaram a relatar também as emoções e os sentimentos pessoais que a visita a lugares distantes lhes suscitava. Com os contributos de Simmel, contudo, este género de narrativa sofreu um aprofundamento epistemológico e filosófico em torno do significado das cidades históricas que ampliou os termos da avaliação dos fundamentos e dos desafios da vida na modernidade em construção.

Apesar da sua pertinência, os textos de Simmel sobre as cidades históricas italianas têm sido muito pouco tratados na comunidade académica portuguesa, ou referidos de forma episódica, 
em regra a partir de fontes secundárias e do trabalho dos comentadores. Nestas circunstâncias, parece-nos decisivo o resgate destes textos originais para a língua portuguesa. ${ }^{1}$

Entre os numerosos aspectos que Simmel traz à nossa compreensão com estes três ensaios "Roma. Uma análise estética" (de 1898); "Florença" (de 1906) e "Veneza" (de 1907) - ressalta a escolha da cidade como objecto estético, em vez de qualquer outro objecto artístico clássico, como um monumento, uma escultura, uma pintura ou uma música. Pode dizer-se que esta escolha é consentânea com a própria filosofia simmeliana, que atribui ao espírito da cidade e à dimensão urbana um estatuto singular, arquetípico da excepcional riqueza e complexidade da vida humana. A cidade, como objecto artístico em Simmel, só pode ser compreendida enquanto totalidade. Mas sempre que aspira a enunciar a natureza estética da cidade enquanto totalidade, o modelo de Simmel engloba, além da obra de arte, também a própria sociedade, enquanto experiência estética (Jankélévitch, 1988; Waizbort, 2000). Deste ponto de vista, a cidade de Simmel, tanto a cidade histórica, como a metrópole moderna, na sua plenitude, constitui-se em categoria alegórica da sociedade mais ampla. Compreende-se deste modo a validade da opção de Simmel pela cidade como obra de arte (Ducret, 1989).

Os textos que aqui se publicam são todos eles, com destaque para "Roma...", subsidiários da reflexão que Simmel acabara de produzir sobre a estética e as suas inter-relações com a cultura e a sociedade. No seu muito apreciado "Estética sociológica", de 1896 (Simmel, 1968), Simmel advoga o princípio do "panteísmo estético", pelo qual a beleza da obra de arte brota apenas da sua totalidade, isto é, da configuração resultante do modo como se interrelacionam os diferentes elementos que a constituem (Frisby, 1985; 1992).

Como resulta das palavras iniciais de "Roma...":

O mais forte atractivo da beleza consiste porventura no facto de ela constituir sempre a forma de elementos que, em si, são indiferentes e alheios à beleza e que só juntos adquirem valor estético. [...] [T]alvez que isto tenha a sua explicação naquela indiferença estética dos elementos e átomos do mundo, que só são portadores de beleza um em relação com o outro, e este apenas na relação com o primeiro, de modo que ela lhes é inerente, é certo, mas não é inerente a nenhum deles isoladamente.

1 Agradecemos à Revista Crítica de Ciências Sociais a autorização para a reprodução deste conjunto de textos que surgiram originalmente no seu número 67, de Dezembro de 2003. 
Entre a publicação de "Roma..." e os restantes "Florença", em 1906, e "Veneza", meses depois, Simmel produziu o seu mais conhecido ensaio sobre a cidade e a metrópole da era industrial "A metrópole e a vida do espírito" (1997 [1903]) que representa a segunda grande influência sobre os textos das cidades antigas. "A metrópole..." é um ensaio de matriz vincadamente sociológica e psicossociológica que tem subjacente duas das principais metrópoles europeias da época (Berlim e Viena), sujeitas ambas, no entender do autor, aos princípios ordenadores da racionalidade capitalista e do anonimato. Será que, à semelhança das cidades antigas, que aliás funcionam como o outro da metrópole moderna, também esta metrópole tem uma estética que condiciona a vida dos sujeitos? Esta é, talvez, a grande interrogação que Simmel faz a si próprio quando recorre à análise das cidades italianas do passado.

Em contraponto ao seu "A metrópole...", Simmel imprime aos textos sobre as cidades italianas uma lógica analítica diferenciada, de feição puramente estética e simbólica. Não significa isto que se opere uma separação radical, digamos, epistemológica, entre os textos sobre as cidades italianas e "A metrópole...". Podemos admitir, aliás de acordo com alguns especialistas (cf. Jonas, 1992), ser mais adequada à compreensão do pensamento simmeliano sobre a cidade e a cultura a junção das lógicas interpretativas diversas que presidem a uns e a outros destes escritos. Para ser fiel à sua própria estratégia metodológica, dir-se-ia que todos eles, à sua maneira, são fragmentos sub specie da análise do espírito da cidade e da dimensão urbana.

Este contraste interpretativo é deliberado e condicionado pelo entendimento que Simmel tem do lugar do elemento histórico-temporal na configuração da cidade e da cultura urbana. No caso dos textos sobre as cidades históricas em que impera uma preocupação com a dimensão histórica, tal opção metodológica revela-se de uma pertinência heurística superior. Como afirma o próprio Simmel,

[S]ão quase só as cidades antigas, crescidas sem um plano premeditado, que oferecem um tal conteúdo à forma estética; aqui, formas que nasceram de finalidades humanas e que aparecem como simples materializações do espírito e da vontade representam pela sua conjugação um valor que está inteiramente para além destas intenções e lhes vem acrescer como um opus supererogationis.

A vantagem civilizacional da cidade antiga e, em particular, de Roma - a cidade eterna - é que ela pode, ou por efeito directo da natureza, ou como "mais puro acaso", reconciliar as tensões 
que dilaceram o mundo, sejam elas as oposições entre espírito e natureza ou entre o presente e o passado. Em manifesto contraste com a metrópole moderna, para Simmel, na sua "unidade espantosa", Roma é uma cidade única, não apenas do ponto de vista da criação artística e estética, mas também, e sobretudo, em vista da sua capacidade para reordenar e re-harmonizar o mundo:

é que as distâncias entre as épocas, os estilos, as personalidades, os conteúdos vitais, que aqui deixaram as suas marcas são tão amplas como em nenhum outro sítio no mundo e, no entanto, estão entretecidas numa unidade, harmonia e afinidade como em nenhum outro sítio do mundo.

Esta ideia da redenção pela arte surge de novo nos textos sobre "Florença" e "Veneza", embora com marcas e efeitos distintos. Roma, dir-se-ia, é uma relíquia, é história em bruto, plena de memórias e de reencontros de diferentes épocas, estilos e personalidades. Florença e Veneza, ao contrário, destacam-se mais enquanto, digamos, cidades-museu. Menos sujeitas ao ordenamento estético do acaso ou da natureza, são tratadas como lugares cenografados, alinhados de acordo com critérios e princípios técnicos especializados, mais do domínio da museologia ou da arqueologia.

Em "Florença" Simmel coloca-se abertamente num denso estilo ensaístico e filosófico, dissertando sobre a relação natureza/espírito e a filosofia da vida numa linguagem tão severa quanto bela. Florença é para Simmel uma "unidade misteriosa", em que natureza e espírito parecem harmonizar-se: "Aqui, a natureza tornou-se espírito, sem renunciar a si própria". Trata-se de uma simbiose manifesta e exclusivamente estética ("Não há talvez mais nenhuma cidade cujo efeito de conjunto (...) gere no observador de modo tão vincado uma impressão de obra de arte"), em que a própria natureza é apresentada sob a forma de cultura, isto é, subordinada a esta última. Tudo em Florença, de Giotto a Michelangelo, dos jardins aos palácios, as igrejas, tanto como o Arno e as próprias colinas florentinas, tudo - "a alma e a manifestação da alma" tem uma harmoniosa forma artística e "quer persuadir-nos de que as partes da realidade se fundem num sentimento do ser".

Esta é uma tensão poderosa, quase telúrica, entre os elementos da vida que o Renascimento pretendeu colmatar, atribuindo ao espírito, e também às ciências e às artes, o encargo supremo de controlar a natureza. No caso de Florença - um bom sinal da preponderância do espírito sobre a natureza - esta tensão encontra-se na forma como a arte e a arquitectura se encarregam 
de eliminar ou embelezar a ruína, que, de outro modo, se insinuaria como poderosa expressão do confronto entre a intenção humana (cultura) e o acontecimento contingente (natureza) (Simmel, 1959 [1911]). Em Florença, a ruína milenária em que se plasma, como em Roma, uma espécie de "vingança" da natureza sobre a violação que o espírito lhe infligira, vê-se, portanto, impedida de gerar harmonia e temperança, como em Roma, em virtude da contínua presença da intervenção humana, estética e artística.

Esta contenção da natureza redentora é, admita-se a tautologia, contra-natura. Para Simmel, o espírito, ainda que aparentemente vitorioso, permanece insatisfeito e só idealmente relacionado com a cidade, o seu passado e o seu presente. Por isso, em Florença, Simmel experimenta um sentimento estético contraditório:

Como aqui, por sobre a natureza, repousa sempre a forma da cultura, como cada passo neste chão toca na história do espírito que com ele se casou de modo inseparável, as necessidades a que só a natureza, no seu ser original, independente de toda a prossecução pelo espírito, pode bastar permanecem insatisfeitas: as fronteiras internas de Florença são as fronteiras da arte.

Florença, em contraste com Roma, só nos reconcilia com a expressão artística e faz-nos resignar perante "o essencial da vida". A cidade toscana limita-se a confirmar a tensão trágica existente entre natureza e espírito, não sob a forma de nostalgia, mas de inevitabilidade. Nem a história nem o passado glorioso e reificado de Florença podem ajudar a recompor esta tragédia da cultura moderna ("O [seu] passado grandioso... tem tristemente pouco que ver com a vida da Florença do presente"). Este é um poderoso argumento sociológico que nos remete para a hipoteca da memória colectiva das comunidades, sempre que estas renunciam ou deixam perder a sua "materialidade estruturante", como diria Maurice Halbwachs.

Por tudo isso, conclui Simmel,

Florença não é um chão próprio para nós em épocas em que queremos começar outra vez de novo, em que queremos confrontar-nos outra vez com as fontes da vida, em que, fugindo aos tumultos da alma, temos de orientar-nos pelo ser inteiramente original.

Veneza é ainda menos do que Florença o terreno a partir do qual Simmel aceita que possa brotar um renovado sentido essencial da vida. Veneza só pode ser uma aventura. 
Veneza surge a Simmel como uma cidade labiríntica, uma cidade de jogos e presunção. Numa palavra, uma cidade artificial. Ao contrário da transparente Florença, em Veneza a arquitectura e as fachadas dos palácios mascaram e ocultam a vida do seu interior. Pelas ruas, "todas as pessoas andam como se estivessem a atravessar um palco [...] para desaparecerem de imediato". Simmel usa aqui e ali uma linguagem teatral e representacional para sublinhar a "mentira" de Veneza. Nesta cidade da fantasia, nem as pontes são pontes, nem as ruas ruas, e até o ano, de tão regular, não tem estações.

Não existe provavelmente outra cidade cuja vida decorra tão integralmente à mesma velocidade. Não há animais de tiro ou veículos a arrastar o olhar que os acompanha em velocidades variadas, as gôndolas têm absolutamente a velocidade e o ritmo de pessoas a caminhar. E é esta a verdadeira causa do carácter "sonhador" de Veneza...

Veneza é tão-só o oposto da cidade moderna e da grande metrópole. Nesse plano ela encontra-se mesmo em oposição a Roma ou Florença, porque o seu ritmo é "demasiado humano" e tão contrastante com a natureza da vida (urbana) moderna que nos conduz "ao estado sonolento do irreal [...] e aproxima-nos do sonho".

O modo como Simmel se refere à cidade de Veneza destaca o engenho e o artifício humanos. Do ponto de vista de uma análise estética, a interrogação que "Veneza" nos coloca, e, deste ponto de vista, o mesmo poderá dizer-se de "Roma" e "Florença", é a do maior ou menor grau de aproximação e similitude destas cidades antigas face à metrópole da viragem do século. Se invertermos os termos da questão, devemos perguntar-nos até que ponto esta metrópole industrial, ela própria o palco da modernidade, se sujeita a uma análise estética, seria ou não capaz de nos atrair como as cidades antigas de Simmel, maxime a artificial Veneza. Ao contrário de outros seus contemporâneos que, optimistas, se rendem perante a chocante beleza da fealdade das metrópoles, Simmel mostra-se cauteloso e ambíguo. A estética da metrópole moderna resultará da capacidade dos sujeitos para resistirem à lógica individualista, calculista, anónima e mesmo psicologicamente perturbadora que domina as interacções na grande cidade. O que é o mesmo que sustentar que, para Simmel, a beleza da metrópole moderna será aquilo que for a qualidade estética das formas de interacção que nela os sujeitos sejam capazes de forjar. 


\section{Referências Bibliográficas}

Boyer, Christine (1998), The City of Collective Memory: Its Historical Imagery and Architectural Entertainments. Cambridge (Mass.): MIT Press.

Ducret, André (1989), "La Ville comme oeuvre d'art", Faces - Journal d'Architectures, 11, 51-54.

Frisby, David (1985), Fragments of Modernity. Cambridge: Polity Press.

Frisby, David (1992), Simmel and Since: Essays on Georg Simmel Social Theory. Londres: Routledge.

Frisby, David; Featherstone, Mike (orgs.) (1997), Simmel on Culture. Londres: Sage.

Jankélévitch, Vladimir (1988), "Introduction: Georg Simmel, philosophie de la vie", in Georg Simmel, La tragédie de la culture et autres essais. Paris: Petite bibliothèque Rivages, 13-87.

Jonas, Stéphane (1992), "Georg Simmel. Sur l'esthétique des Villes Historiques Italiennes", in O. Rammstadt; P. Watier (orgs.), Georg Simmel et les sciences humaines. Paris: Méridiens Klincksieck, 163-178.

Olsen, Donald (1986), The City as a Work of Art. London, Paris, Vienna. New Haven: Yale University Press.

Simmel, Georg (1959), "The Ruin", in Kurt Wolff, Georg Simmel: 1858-1918 (A Collection of Essays). Columbus (Ohio): Ohio State University Press, 259-266 [1911].

Simmel, Georg (1968), "Sociological Aesthetics", in K. Peter Etzkorn (org.), Georg Simmel. The Conflict in Modern Culture and Other Essays. Nova Iorque: Teacher's College Press [1896].

Simmel, Georg (1997), "A metrópole e a vida do espírito", in Carlos Fortuna (org.), Cidade, Cultura e Globalização - Ensaios de Sociologia. Oeiras: Celta, 31-43 [1903].

Waizbort, Leopoldo (2000), As aventuras de Georg Simmel. São Paulo: Editora 34.

Weinstein, Deena; Weinstein, Michael (1993), Postmodern(ized) Simmel. Londres/Nova Iorque: Routledge. 

ROMA. UMA ANÁLISE ESTÉTICA

GEORG SIMMEL 


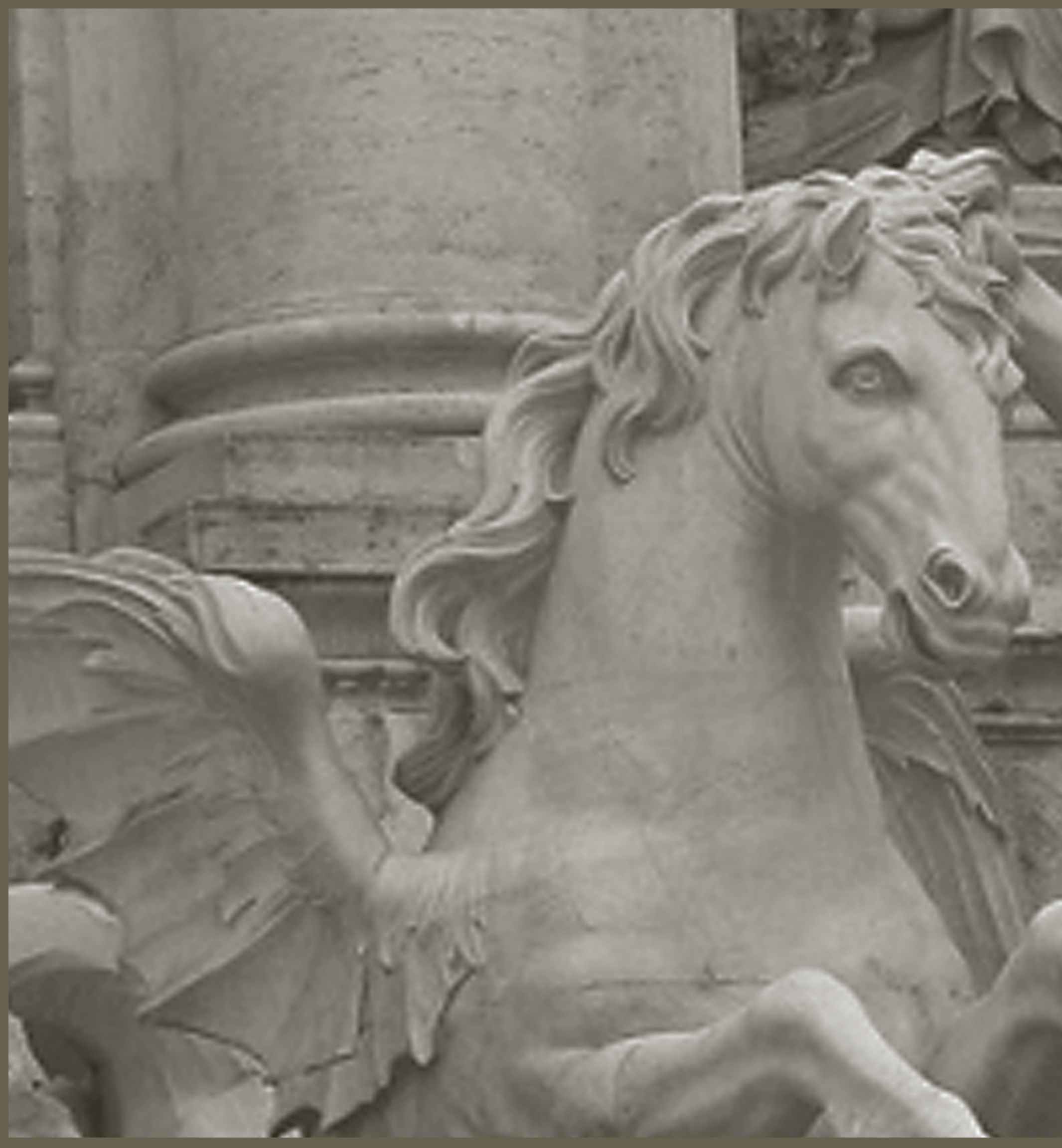




\section{III}

\section{$2 \times$}

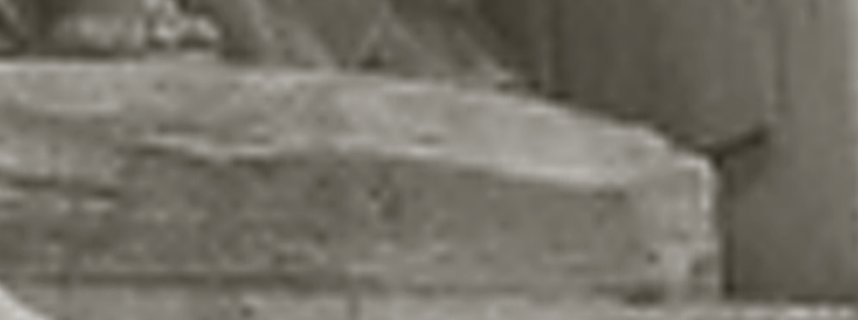


"Rom. Eine ästhetische Analyse", Georg Simmel, Aufsätze und Abhandlungen 1894-1900. Org. Heinz-Jürgen Dahme e David P. Frisby. Frankfurt am Main: Suhrkamp, 1992 [1898]. 
O mais forte atractivo da beleza consiste porventura no facto de ela constituir sempre a forma de elementos que, em si, são indiferentes e alheios à beleza e que só juntos adquirem valor estético; este falta à palavra isolada, como ao fragmento de cor isolado, à pedra ou ao som, e a conjunção formadora que constitui a sua beleza só sobrevém a esses elementos isolados como um presente que, por si sós, eles não merecem. Sentirmos a beleza como um secreto privilégio, como uma coisa que a realidade verdadeiramente não pode exigir, mas apenas aceitar humildemente como uma graça - talvez que isto tenha a sua explicação naquela indiferença estética dos elementos e átomos do mundo, que só são portadores de beleza um em relação com o outro, e este apenas na relação com o primeiro, de modo que ela lhes é inerente, é certo, mas não é inerente a nenhum deles isoladamente.

Ora, nós estamos habituados a ver acontecer este milagre seja na natureza, cujo acaso mecânico forma os seus elementos tanto no sentido da beleza como da fealdade, seja na arte, que reúne esses mesmos elementos de acordo com o objectivo prévio do belo. É muito raro suceder uma terceira eventualidade: obras humanas, criadas para servir um qualquer objectivo da vida, conjugarem-se, para além disso, na forma da beleza, de modo tão ocasional, tão pouco conduzidos pela vontade da beleza na sua junção, como as obras da natureza, que desconhecem toda a finalidade. São quase só as cidades antigas, crescidas sem um plano premeditado, que oferecem um tal conteúdo à forma estética; aqui, formas que nasceram de finalidades humanas e que aparecem como simples materializações do espírito e da vontade representam pela sua conjugação um valor que está inteiramente para além destas intenções e lhes vem acrescer como um opus supererogationis. O mesmo acaso feliz que dá forma aos perfis das montanhas, à cor dos mares, às ramificações das árvores, de acordo com as nossas necessidades estéticas dá aqui boas provas num material que já em si se furta ao acaso, já em si transporta a finalidade e o espírito, se bem que não o espírito da beleza; da mesma forma que as acções humanas, totalmente conduzidas e preenchidas pela individualidade e a estreiteza dos seus objectivos, se conjugam, no entanto, para a realização do plano divino universal, do qual nada sabem.

No rosto urbano de Roma, essa fusão afortunadamente casual de criações funcionais do ser humano para atingir uma nova beleza involuntária parece adquirir o seu supremo fascínio. Aqui, gerações incontáveis criaram e construíram ao lado umas das outras e por cima umas das outras, cada uma delas sem se importar minimamente ou mesmo, a maior parte das vezes, sem compreender minimamente o que encontrava já feito, entregue exclusivamente às necessidades do presente e ao gosto ou ao capricho da sua época; foi o mais puro acaso que decidiu 
que forma global havia de resultar do mais antigo e do mais recente, do que caía em ruínas e do que era preservado, do que se harmonizava e do que destoava. E como o conjunto, apesar disso, ganhou uma unidade tão espantosa como se uma vontade consciente tivesse reunido os seus elementos na busca da beleza, o poder do seu fascínio resulta agora certamente desta distância ampla e, contudo, harmónica entre o carácter ocasional das partes e o sentido estético do conjunto; é nisto que reside a garantia deleitosa de que todo o sem-sentido e desarmonia dos elementos do mundo não impede que eles se conjuguem na forma de uma totalidade bela. O que é inteiramente incomparável na impressão transmitida por Roma é que as distâncias entre as épocas, os estilos, as personalidades, os conteúdos vitais, que aqui deixaram as suas marcas são tão amplas como em nenhum outro sítio no mundo e, no entanto, estão entretecidas numa unidade, harmonia e afinidade como em nenhum outro sítio do mundo.

Se tentarmos decompor o efeito estético de Roma de uma perspectiva psicológica, vai-se dar, seja qual for a direcção tomada, sempre a este centro, indicado desde logo pela imagem exterior da cidade: o facto de as maiores antinomias de acordo com as quais se cindiu a história da cultura elevada terem aqui resultado numa unidade plena, orgânica, da impressão. ${ }^{2}$ Tal como a essência do reconhecimento consiste em formar uma imagem do mundo inteligivelmente coerente a partir das sensações fragmentárias e isoladas dos sentidos; tal como incumbe à moralidade conciliar numa unidade os interesses desconexos ou antagónicos; assim um dos motivos últimos da fruição estética consiste em encontrar ou criar uma unidade na massa caótica das impressões, ideias, sugestões. Se uma marca do humano, ou mesmo talvez a mais profunda marca do humano, consiste em extrair da multiplicidade original das coisas e das representações uma união comum na alma, talvez toda a arte seja apenas uma maneira especial de conseguirmos isto, apenas uma das vias que levam da multiplicidade exterior - ou também interior - à unidade interior, e a importância de cada obra de arte cresceria na medida em que a multiplicidade das suas condições, do seu material, da sua problemática, seja mais diversa e a unidade em que ela é capaz de prendê-la seja mais estreita, mais forte, mais homogénea. Neste sentido, Roma produz o efeito de uma obra de arte da mais elevada ordem. Isto começa com a configuração das suas ruas, na forma como esta é determinada pelo acidentado do terreno. Quase por todo

2 Posso aqui deixar inteiramente de lado as partes de Roma que são de uma modernidade ininterrupta e de uma não menos ininterrupta hediondez; por sorte, elas estão situadas de uma forma que leva a que, desde que haja algum cuidado, só relativamente pouco afectem o forasteiro. A última vez que tinha estado em Roma era há mais de vinte anos e fui encontrá-la agora, no essencial, menos mudada do que correntemente se diz. 
o lado os edifícios situam-se numa relação recíproca entre cima e baixo. Assim, referem-se uns aos outros de modo muito mais significativo do que se estivessem situados numa superfície plana, simplesmente uns ao lado dos outros. Talvez seja este o encanto elementar de uma paisagem montanhosa: tudo o que está num plano superior só é possível como tal através do que se situa num plano inferior, e inversamente; assim, as partes do todo ganham uma relação incomparavelmente estreita, a sua unidade, que aqui como em geral assenta simplesmente na relação recíproca entre as partes, torna-se directamente visível. Quando os elementos de uma paisagem se situam no mesmo nível, tornam-se mais indiferentes uns em relação aos outros, cada um detém, por assim dizer, a sua própria posição, ao passo que, ali, ela é-lhe determinada pelo outro. É assim que a forma como Roma está edificada é capaz de reconduzir a uma unidade claramente estreita o carácter ocasional, contraditório, sem princípios, inerente à história da sua construção. Através do superior e do inferior, as linhas erráticas do perfil da cidade recebem directivas precisas, aparecendo agora todos os pormenores como seus suportes solidários. A dinâmica da vida urbana em Roma age no mesmo sentido: nenhum elemento, por mais arcaico, insólito, inútil que seja, pode furtar-se à sua enorme vivacidade. Mesmo o que é mais renitente é arrastado por esta corrente. A inserção de restos antigos e clássicos em edifícios posteriores constitui simbolicamente, ou numa forma inerte, o mesmo que a dinâmica da vida romana apresenta em forma fluida: a construção de uma unidade vital própria a partir de elementos imensamente diferentes, que, pela amplitude do seu espectro, tornam aquela unidade visível de um modo de outra forma nunca alcançado. Por isso é que em Roma também tudo aquilo para que, infelizmente, não temos outra expressão senão a de curiosidade turística, não produz o mesmo efeito que noutros lados, como pontos de interesse isolados, independentes do restante, especialmente salientes, que poderiam estar também perfeitamente situados num outro lugar qualquer; pelo contrário, eles são componentes do todo, cada um dos quais está numa relação orgânica com todos os outros, ligados pela unidade abrangente de Roma. Por isso também o turista típico em Roma tem um aspecto ainda mais despropositado e insuportável do que o normal: porque ele só presta atenção às "curiosidades turísticas" isoladas como tais, de modo que a soma delas, para ele, corresponde a Roma, o que é o mesmo do que dizer que um corpo orgânico é igual à soma anatómica dos seus membros, passando ao lado do processo da vida em si mesmo, para o qual cada membro é apenas um órgão da sua unidade que tudo prende, tudo penetra, tudo domina. Esse turista não sente a beleza à segunda potência que se erege a partir das belezas no singular e sobre elas. 
A fusão do mais díspar numa unidade, que caracteriza a imagem espacial de Roma, ganha uma eficácia não menos real na forma do tempo. De um modo totalmente único, difícil de descrever, sente-se aqui como o carácter de mútua exterioridade dos tempos se vai transformando numa relação de conjunção e de entrosamento. Ouve-se exprimir isto na frase de que, em Roma, o passado se torna presente para nós, ou também, inversamente, que o presente se torna para nós tão nebuloso, sobre-subjectivo, repousado, como se fosse um passado. Com essa frase, exprime-se apenas, partindo de pontos diferentes, o que em si não tem pontos diferentes, a intemporalidade, a unidade da impressão, que não é capaz de separar à força o antes ou o depois que lhe estão associados, transportados apenas pelo entendimento reflexivo. É certo que a ideia do curso histórico das coisas nunca desaparece em Roma. Mas o que é extraordinário é que também aqui, na dimensão temporal, os elementos só parecem estar tão afastados uns dos outros para mostrar tanto mais vigorosamente, incisivamente, abrangentemente, a unidade em que, apesar disso, se fundem. Tal como aqui os restos da antiguidade adquiriram uma nova forma na sua destruição e através desta, também a ideia que ressoa em toda a parte da sua mútua exterioridade temporal actua apenas como uma nuance por assim dizer estética da sua imagem presente; a continuidade dos tempos, que preenche continuamente a consciência em Roma de um modo evidente, impede o isolamento entre si do que está temporalmente separado; assim, as coisas adquirem um nível comum, no qual se confrontam apenas de acordo com os seus conteúdos substanciais. Justamente devido à amplitude enorme dos espaços de tempo abrangidos, o ponto de vista do tempo torna-se inteiramente irrelevante para uma coisa isolada, esta já não aparece como presa à sua situação temporal, de modo que só poderia ser fruída se nos transpuséssemos para essa situação, antes adquire, inserida na imagem global de Roma, uma vitalidade totalmente directa; tudo o que é histórico colabora nesta, é certo, mas não de maneira a tornar-se objecto de uma antiguidade separada, afastada das condições do presente; pelo contrário, ao juntar-se à unidade de Roma, ele produz um efeito inteiramente de acordo com o seu significado substancial objectivo - como se toda a casualidade da história tivesse desaparecido e os conteúdos puros, libertos, das coisas - na linguagem platónica, as suas ideias - se destacassem a par uns dos outros.

Este sentimento, que só aproximativamente pode ser expresso por palavras, constitui talvez o fundamento último daquela profunda frase de Feuerbach: que Roma indica a cada um o lugar que lhe pertence. O indivíduo que toma consciência de si próprio no seio desta imagem de conjunto perde a posição que lhe foi concedida pelo seu círculo histórico-social estreito 
e fechado e vê-se de repente inserido e participante num sistema de valores imensamente variados, com o qual tem que se medir por assim dizer de modo objectivo. É como se em Roma ficássemos despojados de tudo o que as condições temporais fizeram em nós - a favor e contra o verdadeiro cerne do nosso ser. Nós próprios sentimo-nos igualmente reduzidos à nossa força e importância puramente interiores, tal como os conteúdos de Roma são puramente interiores. Não conseguimos furtar-nos à sua força unificadora, que reúne todas as coisas numa imagem de conjunto, independentemente de todos os abismos do tempo, acabamos por nos encontrar, como que libertos de todo o agora e aqui, na mesma distância em relação a nós que todas as coisas de Roma. Teríamos vergonha de reivindicar neste ponto um lugar especial. Aquilo que noutras situações nos esconde tantas vezes o lugar que nos corresponde conforme a força, amplidão e disposição da nossa alma - os acasos do tempo, os exageros e os constrangimentos da nossa posição histórica, que nos isolam e bloqueiam a ponte para a nossa pátria interior - isso em Roma desaparece, porque aqui, onde todas as condições histórico-temporais se revelam em toda a sua grandeza e, ao mesmo tempo, em toda a sua justeza final, as coisas - e nós com elas - só têm valor para nós na medida do seu valor objectivo mais íntimo e intemporal. Assim, Roma indica-nos verdadeiramente o lugar que nos pertence, ao passo que o lugar que estamos habituados a ocupar interiormente tantas vezes não é de todo o nosso, mas o da nossa classe, dos nossos destinos unilaterais, dos nossos preconceitos, das nossas ilusões egoístas. O facto de tudo isto desaparecer deve-se, em última análise, àquele traço que domina toda a imagem de Roma: a espantosa unidade do multiforme, que não é destruída pelo vasto espectro dos seus elementos, mas se serve justamente deste para desenvolver o incomparável da sua força. Tal como o fascínio misterioso de velhos tecidos assenta no facto de os destinos comuns, o sol e a sombra, a humidade e a secura de tantos anos terem dado a todos os contrastes das cores uma unidade e harmonia que de outro modo não seriam possíveis, assim também pode dizer-se que o mais distante e mais estranho entre si, o que, segundo o tempo, a origem, a alma, está infinitamente separado, conheceu, através da experiência comum de estar em Roma e de partilhar do destino de Roma, uma adaptação mútua, uma interacção, um entrosamento em tão extraordinárias condições que o significado próprio das coisas é maximizado ao mesmo tempo que o significado da unidade na qual se fundem como membros.

É justamente esta unidade que provoca no seio da fruição de Roma um fenómeno psicológico que, normalmente, surge apenas perante as individualidades de máxima dimensão. 
O património que Goethe representa para nós adquire o seu alcance incomensurável pelo facto de, por detrás de cada uma das suas afirmações, estar para nós o Goethe inteiro. Nós não fruímos nenhuma dessas afirmações apenas pelo seu conteúdo directo, não limitamos o seu significado ao sentido que teria se fosse uma frase anónima; pelo contrário, enriquecemo-las com tudo aquilo que a associação de que elas se devem justamente a Goethe lhes acrescenta, nelas faz ressoar. O filisteu racionalista faz troça do respeito entusiástico com que abordamos cada linha de Goethe: "Se um anónimo tivesse escrito exactamente o mesmo, ninguém fosse onde fosse lhe daria o mínimo de atenção!" É verdade. Mas então, mesmo que fosse textualmente idêntica, não seria, justamente, a mesma linha. Porque o sentido de todo o enunciado está precisamente - nunca é de mais insistir nesta evidência - apenas naquilo que ele nos estimula a pensar e nos obriga a pensar. E uma frase de Goethe faz-nos pensar necessariamente mais e coisas diferentes do que a mesma frase pronunciada por um qualquer; porque nós sabemos que uma alma muito diferente revestiu aqui a sua riqueza na roupagem que por fora é idêntica e que a única forma de fazermos mesmo justiça à frase é atribuir-lhe o máximo e o mais elevado que em nós queira de alguma forma associar-se a ela - na medida em que isto transcenda também o sentido que ela poderia reivindicar como expressão isolada. Assim, coisas que num outro lugar seriam inteiramente indiferentes, têm, como componentes de Roma, um sentido que transcende em muito o seu sentido imediato, aquele que "em si" lhes é próprio. Por obra da homogeneidade em que Roma faz que se fundam todos os seus conteúdos, o conjunto torna-se solidário com cada um dos seus elementos. Por detrás de cada um destes está Roma inteira, emprestando-lhe para nós uma abundância de associações que abrange muito mais do que seria capaz a sua contemplação isolada ou inserida em relações mais indiferentes e menos estreitas. Como as coisas são, justamente, aquilo que significam para nós, em Roma elas são verdadeiramente mais do que seriam alhures e sem o enriquecimento recíproco que lhes dá o amplexo da Roma que é uma.

Talvez que a significação mais profunda da configuração estética possa exprimir-se numa frase de Kant, mesmo tendo esta em mira conteúdos que não são de todo estéticos: "Entre todas as representações, a ligação é a única que não é dada por objectos, antes pode ser realizada apenas pelo próprio sujeito, porque é um acto resultante da sua actividade autónoma." A unidade em que se ligam os elementos de Roma não está neles, mas sim no espírito que os contempla. É que, manifestamente, ela só se concretiza numa cultura determinada, sob condições determinadas de ambiente e de nível cultural. Isso, porém, contradiz tão pouco o seu 
significado que a actividade autónoma que ela exige é, precisamente, o mais valioso presente que Roma tem para oferecer. Só a acção mais viva, mesmo que inconsciente, do espírito é capaz de prender elementos tão infinitamente diferentes numa unidade que reside nela própria, é verdade, como possibilidade, mas ainda não como realidade. Se não sufocamos em Roma, antes nos sentimos precisamente chegados ao cume da personalidade, isso é seguramente um reflexo da actividade autónoma do ser interior, intensificada de maneira extraordinária. Em nenhum lugar do mundo um acaso feliz ordenou os objectos do nosso espírito de modo tão adequado que eles o convocam a desenvolver a energia capaz de os reunir numa unidade plena, independentemente das enormes distâncias da sua existência imediata. Essa é também a razão por que Roma fica gravada na memória de forma completamente inapagável. Quando as impressões e as fruições só nos prendem de modo superficial e, de certo modo, sem que nós intervenhamos na configuração da sua imagem interior com uma demonstração de energia própria, toda a memória é débil e facilmente se apaga. Pois, por mais poderosa e perturbadora que tenha sido a impressão, ela, apesar disso, não é para o mais íntimo da alma senão um corpo estranho que não pode viver nela por muito tempo - como é que, de outro modo, seriam pensáveis aquelas terríveis discórdias entre amantes, se não se desse o caso de o simples sentimento, a simples aceitação de uma felicidade, mesmo nos mais extremos auges, abandonar a consciência sem deixar qualquer rasto! Só quando a alma se tornou activa a partir de dentro e misturou a trama da sua actividade mais própria nas impressões vindas do exterior é que estas se tornaram verdadeiramente suas. A consciência sub-humana ou de uma baixa humanidade está presa ao carácter isolado das suas representações, a marca de uma consciência superior e a prova da sua liberdade e do seu domínio é o facto de gerar relações entre o que é particular e, assim, ao mesmo tempo - já que a unidade e a multiplicidade se condicionam mutuamente -, experimentar toda a variedade e riqueza dele. Em nenhum lugar a plenitude das coisas permite que esta acção especificamente humana se demonstre de modo tão soberano como em Roma, em nenhum lugar a alma, ao mesmo tempo que absorve tantas coisas, tem, ao mesmo tempo, que agir tanto para formar a imagem. É esse o fundamento último da relação totalmente incomparável que a amplitude das impressões de Roma possui relativamente à sua profundidade e à sua duração - como se todas as dimensões dos conteúdos espirituais atingissem aqui ao mesmo tempo o seu máximo.

O destino das análises psicológicas é nunca serem conclusivas. A alma humana é uma estrutura tão multiforme e tão intrincada que possui vias muito variadas para atingir o mes- 
mo conteúdo e o mesmo estado. A sua riqueza está, justamente, em ser capaz de desdobrar os mesmos elementos numa multiplicidade de oposições internas, mas também de desdobrar os mais diversos elementos numa homogeneidade de efeitos internos. Mas se, por isso mesmo, o sentido da impressão estética de Roma pode ser explicado ainda de toda uma série de outras maneiras, a estrutura do objecto encontra-se de modo muito singular com a dos sujeitos para produzir esta possibilidade. Pois, tal como a grandeza dos grandes seres humanos reside em não ser unívoca, antes ser compreensível por cada um de uma forma particular, elevando cada um para além de si próprio na direcção da sua própria essência, assim também Roma não teria toda a sua grandeza se a sua fruição apenas admitisse uma interpretação, se ela não se assemelhasse à própria natureza, que fala para cada um na sua própria língua e permite a cada um fruí-la e entendê-la de acordo com o seu coração. É que, justamente, esta pluralidade dos efeitos de Roma e das suas interpretações corresponde ela própria ao princípio vital de que me parece brotar a sua singularidade estética. Poder ser sentida ainda de tantas outras maneiras e a maneira como é sentida poder ser interpretada ainda de tantas outras maneiras, ao mesmo tempo que continua, em última análise, a ser sempre uma Roma que é um foco de raios tão divergentes: é esse o auge supremo da sua grandeza estética, que distende todas as oposições até à máxima amplitude, para as conciliar na sua unidade com uma energia tanto mais dominadora. 


\section{FLORENÇA}

GEORG SIMMEL 


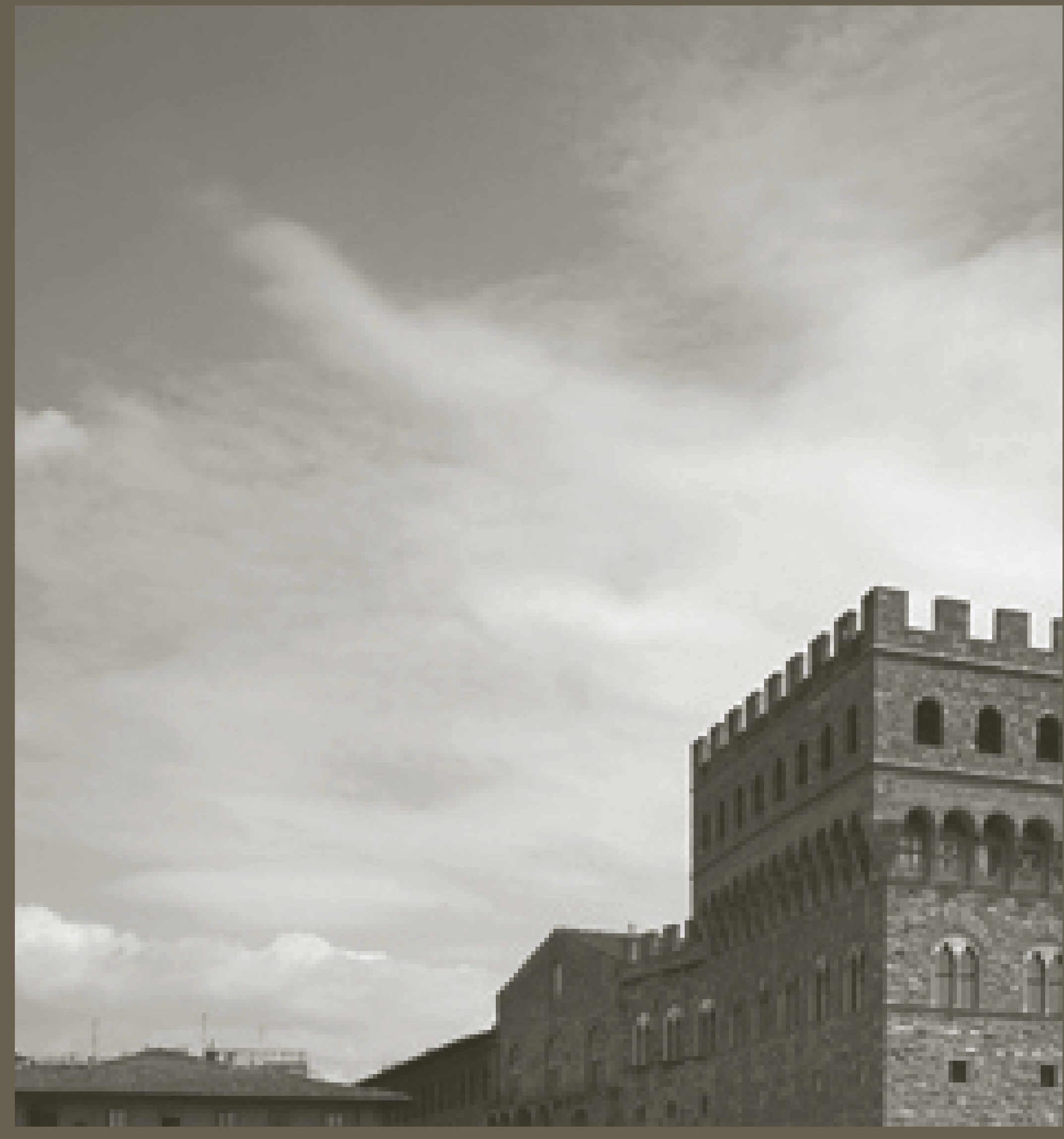


"Florenz", Georg Simmel, Aufsätze und Abhandlungen 1901-1908, vol. 2. Org. Rüdiger Kramme et al. Frankfurt am Main: Suhrkamp, 1995 [1906]. 
Desde que o sentimento unitário da vida da Antiguidade se cindiu nos pólos da natureza e do espírito; desde que a existência imediata e evidente descobriu a sua estranheza e oposição quando confrontada com um mundo do espírito e da interioridade; desde esse momento estava equacionado o problema cuja percepção e tentativas de resolução preenchem toda a era moderna: o problema de reconquistar para ambas as partes da vida a unidade perdida.

Isto, contudo, só parece estar plenamente ao alcance da obra de arte; só aqui a forma dada pela natureza se revela como o espírito tornado manifesto. Aqui, este já não está escondido atrás do visível-natural, pelo contrário, os elementos tornaram-se tão indistinguivelmente unidos como eram antes da separação pelo processo da vida histórica.

Quando, porém, se olha para Florença do alto de S. Miniato, se vê como a cidade está emoldurada pelos seus montes e é atravessada pelo seu Arno como por uma artéria vital; quando, de tarde, com a alma repleta da arte das suas galerias e palácios e igrejas, se passeia pelas suas colinas, com as suas vinhas, oliveiras, ciprestes, onde não há um pedacinho dos caminhos, das vilas, dos campos, que não transborde de cultura e de passados grandiosos, onde uma camada de espírito os rodeia como um corpo astral desta terra - então nasce um sentimento como se a oposição entre natureza e espírito se tivesse aqui tornado insignificante.

Uma unidade misteriosa e, contudo, como que a meter-se pelos olhos dentro, a saltar aos olhos, enlaça a paisagem, o aroma do seu chão e a vida das suas linhas, com o espírito, que é o seu fruto, juntamente com a história do ser humano europeu, que aqui ganhou forma, com a arte, que aqui surge como um produto da terra.

Compreende-se que foi neste lugar que nasceu o Renascimento, o primeiro sentimento de que toda a beleza e significação que a arte busca surgem como um desenvolvimento da manifestação natural das coisas, e que os artistas da Renascença, mesmo os da mais soberana estilização, podiam legitimamente ser de opinião que se limitavam a copiar a natureza.

Aqui, a natureza tornou-se espírito, sem renunciar a si própria.

Cada uma destas colinas simboliza a unidade em que os contrastes da vida se irmanam: na medida em que cada uma delas culmina numa vila, numa igreja, a natureza parece tender por todo o lado para a coroação pelo espírito.

A cada passo, uma terra fértil a ir ao encontro da cultura; e, no entanto, nada da opulenta superabundância do Sul, que violenta o ser humano.

Há uma riqueza tropical tanto do ser exterior como do interior com que nenhuma arte pode competir; a esta riqueza aqui, porém, a força humana pôde dar forma por si própria. 
Quando Benozzo Gozzoll e outros pintam esta paisagem como um jardim - dividida, com canteiros, sebes, árvores bem ordenadas -, isso deve-se a este último traço da vida florentina: eles não conseguem conceber idealmente a natureza senão como configurada pelo espírito.

É ao resolver-se assim a tensão entre a natureza e o espírito que surge a disposição estética, o sentimento de estar perante uma obra de arte.

Não há talvez mais nenhuma cidade cujo efeito de conjunto, o que se oferece aos olhos e o que pertence às suas memórias, a sua natureza e a sua cultura em cooperação, gere no observador de modo tão vincado uma impressão de obra de arte, incluindo nos aspectos mais exteriores: mesmo os montes escalvados por detrás de Fiesole, que não mostram, como mostram todas as colinas mais próximas, traços de actividade humana, têm um efeito que não é senão o de enquadramento da imagem marcada pelo espírito e pela cultura e são, assim, absorvidos pelo carácter de conjunto dessa imagem como a moldura é absorvida pelo quadro, de cujo sentido está ao serviço justamente por ser diferente, porque, assim, lhe dá coesão como um organismo que existe por si, que se basta a si próprio.

A unidade da imagem de Florença dá a cada um dos seus pormenores um significado mais profundo e mais amplo, só comparável ao significado que o pormenor da obra de arte adquire ao ser integrado nesta.

Papoilas e giestas, vilas, cerradas como segredos, e crianças a brincar, azul e nuvens do céu - sendo tudo isto coisas que podem encontrar-se em qualquer lugar do mundo e que são belas em toda a parte, aqui, contudo, recebem um peso estético-espiritual e um enquadramento muito diferentes, porque nada encanta apenas pela sua beleza isolada, antes participa de uma beleza de conjunto englobante.

E não é apenas a contiguidade entre todos os elementos visuais e entre natureza e espírito, mas também a sucessão de passado e presente que concentra a impressão de Florença e da sua paisagem como que num único ponto.

O passado grandioso, é certo, tem tristemente pouco que ver com a vida da Florença do presente, mas ele vive por si com demasiada força, sensibiliza-nos de modo demasiado directo para que o sentimento romântico do fosso entre outrora e hoje possa ganhar peso.

É verdade que os elementos do romantismo estão presentes por todo o lado: o muro velho que acompanha a encosta da montanha, a vila no alto com os ciprestes negros, as torres solitárias dos castelos nas cercanias - tudo isto é especificamente romântico, mas sem nenhuma da nostalgia do romantismo alemão, em que tudo chora algo perdido, que talvez nunca tenha existido. 
Porque o passado permaneceu visível e, assim, possui uma presença própria, que se perfila junto com a outra, a que é inerente à actualidade, sem, no entanto, a tocar.

O tempo não gera aqui uma tensão dilacerante entre as coisas, como o tempo real, antes se assemelha ao tempo ideal em que vive a obra de arte, o passado aqui pertence-nos, como a natureza, que também é sempre presente.

Todo o romantismo vive daquela tensão entre a realidade e o passado, o futuro, a idealidade, a possibilidade, ou também a impossibilidade.

Esta paisagem, porém, é como um retrato italiano, em cujos traços também tudo está exposto, tudo está presente, traços que, no fim de contas, dizem tudo o que têm a dizer - num contraste essencial com o tipo nórdico das pessoas, que se revela através de outros meios: através de alusões, modos de iluminar, simbolizações, sínteses, em que os conteúdos nucleares não surgem, justamente, ao lado uns dos outros, antes exigem do observador um reviver da sucessão da vida.

A paisagem de Florença carece de todo o carácter simbólico que possuem os Alpes e a charneca, o bosque e o mar. Ela não significa nada, é o que pode ser. Por via de tudo isto, a vida ali torna-se tão singularmente plena como se se fechassem as falhas que normalmente lhe sobrevêm da discórdia dos seus elementos.

É como se esta cidade procurasse em todos os recantos da alma tudo o que é maduro, alegre, cheio de vida, e construísse a partir disso um todo, tornando sensível de repente a sua conexão e unidade internas.

Mas o que Florença é obrigada a recusar, porque existe justamente esse todo, é algo que como se para, apesar de tudo, compensar isso tanto quanto possível - está simbolizado dentro de si própria: na Capela dos Medicis. Esta é muito mais romana do que florentina.

O destino de ter um passado tão extraordinário, independentemente do que tenha sido o seu conteúdo - este destino pesa sobre Roma e dá ao seu ritmo de vida uma dignidade grave, uma tensão trágica, que, em Florença, se resolve, lá onde a vida como que abre os braços para receber com amor todo e qualquer passado.

As figuras de Michelangelo, porém, carregam aquela sina de um passado não redimido, elas estão todas como que possuídas de espanto sobre a incompreensibilidade da vida, sobre a incapacidade da alma de reunir todas as dilacerações dos destinos na unidade de um sentimento da vida.

E Michelangelo deu à unidade florentina entre a natureza e o espírito um toque não menos trágico. É verdade que o interior e o exterior, a alma e a manifestação da alma, estão unidos 
harmoniosamente na forma artística que ele lhes deu. Mas a tensão entre ambos é tão poderosa, mais, é tão violenta, que eles ameaçam continuamente cindir-se e só preservam a sua unidade como que por uma convocação permanente das últimas reservas de energia.

É como se ele tivesse captado todas as figuras no momento em que, nelas, a luta entre o fardo sombrio do peso terreno e a ânsia do espírito por luz e liberdade se imobilizou.

Não há um traço em Michelangelo que não ensine que a unidade em que a arte exprime a vida contém em si duas partes inconciliáveis; a imagem de Florença - da sua paisagem, da sua cultura, da sua arte - quer persuadir-nos de que as partes da realidade se fundem num sentimento do ser.

Assim, ambos exprimem o mesmo, mas, conforme o acento recai sobre a duplicidade em toda a unidade ou sobre a unidade em toda a duplicidade, assim dois mundos se separam, entre os quais a vida mais íntima tem de optar, renunciando a uma se quer possuir a outra.

E agora, uma última observação. Como aqui, por sobre a natureza, repousa sempre a forma da cultura, como cada passo neste chão toca na história do espírito que com ele se casou de modo inseparável, as necessidades a que só a natureza, no seu ser original, independente de toda a prossecução pelo espírito, pode bastar permanecem insatisfeitas: as fronteiras internas de Florença são as fronteiras da arte.

A terra de Florença não é uma terra sobre a qual nos deixemos cair para sentir bater o coração do ser no seu calor escuro, na sua força informe - como o podemos sentir no bosque alemão e junto ao mar e mesmo num qualquer jardinzinho de uma anónima cidade de província.

Por isso é que Florença não é um chão próprio para nós em épocas em que queremos começar outra vez de novo, em que queremos confrontar-nos outra vez com as fontes da vida, em que, fugindo aos tumultos da alma, temos de orientar-nos pelo ser inteiramente original. Florença é a boa fortuna das pessoas totalmente amadurecidas, que alcançaram o essencial da vida ou que renunciaram a ele e que já não querem senão buscar a forma adequada a essa posse ou a essa renúncia. 
VENEZA

GEORG SIMMEL 







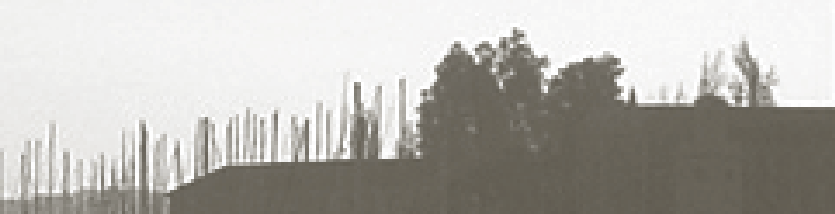

"Venedig", Georg Simmel, Aufsätze und Abhandlungen 1901-1908, vol. 2. Org. Rüdiger Kramme et al. Frankfurt am Main: Suhrkamp, 1995 [1907]. 
Há uma exigência de verdade que impende sobre a arte e está para além de todo o naturalismo, que impõe à arte a lei das coisas que lhe são exteriores: um imperativo que a obra de arte tem de realizar, embora ele brote apenas dela própria.

Se um vigamento poderoso assenta em colunas que não julgamos capazes de tal esforço, se as palavras patéticas de um poema apontam para uma paixão e uma profundidade cujo conjunto, todavia, não nos convence, sentimos a falta de uma verdade, de uma concordância da obra de arte com a sua própria ideia.

Mas mais uma vez ela se vê perante a decisão entre a verdade e a mentira, porque pertence a uma totalidade do ser.

De um modo dificilmente decifrável, desenha-se por detrás de toda a obra de arte o querer e o sentir de uma alma determinada, de uma concepção determinada do mundo e da vida - mas de modo nenhum isso acontece sempre de modo a que a obra seja a expressão fiel e apropriada daquela realidade mais profunda, mais geral, que, todavia, nos leva a experimentar a sua textura.

Pelo contrário, por extraordinário que pareça, muitas obras de arte apontam directamente para um mundo interior e metafísico que nelas deveria exprimir-se, mas, na realidade, não se exprime.

As partes podem estar em harmonia umas com as outras e ser perfeitas, mas o todo brota de uma raiz a que não pertence e, quanto mais acabado for em si mesmo, mais radical é a mentira, quando ele se insere no contexto de uma vida interior, uma visão do mundo, uma convicção religiosa, que, no seu ser mais profundo, desmente.

As diferentes artes participam em diferente medida nessas verdades e nessas mentiras.

Nenhum naturalismo pode colocar a exigência de verdade à arquitectura, de que aqui irá tratar-se, no sentido da identidade formal com algo exteriormente dado; ela exige tanto mais visivelmente a verdade interior: que as bases de apoio sejam suficientemente robustas para os pesos que têm de suportar, que os ornamentos encontrem o lugar em que podem viver plenamente a sua dinâmica interna, que os pormenores não sejam infiéis ao estilo que configura o todo.

É mais misteriosa, porém, a harmonia ou o contraste em que o edifício se situa relativamente ao significado espiritual ou ao sentido da vida que lhe está ligado, que nele se vislumbra mas apenas como uma exigência que ele coloca a si próprio, é certo, mas, apesar disso nem sempre cumpre.

Talvez consista nisto a diferença mais profunda entre a arquitectura de Veneza e a de Florença. 
Nos palácios de Florença, de toda a Toscana, sentimos o lado exterior como expressão exacta do seu sentido interior: altaneiros, acastelados, manifestação austera ou faustosa de um poder que se faz sentir em cada pedra, cada um deles a representação de uma personalidade segura de si própria, responsável apenas perante si própria.

Os palácios venezianos, pelo contrário, são um jogo precioso, eles mascaram já pela sua uniformidade as personalidades individuais dos seres que os habitam, são um véu cujas dobras obedecem apenas às leis da sua própria beleza e só deixam entrever a vida por detrás dele ocultando-a.

Toda a obra de arte interiormente verdadeira, por mais fantástica e subjectiva que seja, exprime uma forma de possibilidade da vida.

Se, porém, percorremos o Canal Grande, sabemos: seja a vida como for - assim é que de todo em todo não pode ser.

Aqui, na Praça de São Marcos, na Piazzetta, sente-se uma férrea vontade de poder, uma paixão sombria, que, como a coisa em si, subjazem a esta aparência risonha: mas a aparência vive como que numa separação ostensiva do ser, o lado exterior não recebe qualquer directiva e alimento do lado interior, não obedece à lei de uma realidade espiritual envolvente, mas sim à lei de uma arte que parece, justamente, estar destinada a desmentir essa lei.

Porém, quando o sentido da vida desaparece atrás da arte, por mais perfeita que ela seja, ou quando caminha na direcção oposta, então ela torna-se artificialidade.

Florença produz o efeito de uma obra de arte porque a imagem que transmite está ligada a uma vida que desapareceu historicamente, é verdade, mas que, no plano ideal, lhe é fielmente inerente.

Veneza, porém, é a cidade artificial.

Florença não pode nunca tornar-se uma simples máscara, porque a sua manifestação era a língua sem disfarces de uma vida verdadeira; aqui, porém, onde tudo o que era alegre e claro, ligeiro e livre, servia simplesmente de fachada a uma vida sombria, violenta, implacavelmente funcional, o seu declínio deixou apenas um cenário sem alma, a beleza mentirosa da máscara.

Em Veneza, todas as pessoas andam como se estivessem a atravessar um palco: nos seus zelosos afazeres, com que nada fazem, ou nos seus devaneios vazios, surgem constantemente a dobrar uma esquina para desaparecerem de imediato numa outra e têm nisso sempre alguma coisa de actores, que à direita e à esquerda da cena não são nada, a representação só acontece ali e não tem qualquer motivação na realidade do antes, nem qualquer consequência na realidade do depois. 
Segundo a lógica da unidade através da qual uma obra de arte sujeita todos os seus elementos ao seu sentido global, assim aqui o carácter superficial se apossa da imagem das pessoas.

O modo como se movem e ficam parados, como compram e vendem, como olham e falam tudo isso nos parece, desde o momento em ficamos subjugados pelo ser desta cidade, que consiste na separação entre a aparência e o ser, como algo apenas bidimensional, como que colado sobre o que é real e definitivo na sua natureza.

Mas, como se esta natureza se tivesse consumido sob isso, todo o fazer é um diante que não tem detrás, um termo de uma equação cujo outro termo foi apagado.

Mesmo a ponte perde aqui a sua força revivificadora.

Normalmente, ela é capaz do feito incomparável de realizar de um só golpe a tensão e a conciliação entre dois pontos no espaço, de, movendo-se entre eles, tornar sensível a sua separação e a sua união como uma e a mesma coisa.

Esta dupla função, porém, que confere à forma apenas pitoresca da ponte uma vivacidade com um sentido mais profundo, está aqui desvanecida, as ruas deslizam como que sem intervalos por sobre as inúmeras pontes, por mais alto que se estenda o arco da ponte ele é simplesmente como que um respirar fundo da rua, que não interrompe a continuidade do seu curso.

E é exactamente da mesma forma que as estações do ano deslizam por esta cidade, sem que a transição do Inverno para a Primavera, do Verão para o Outuno, modifique a sua forma exterior de modo palpável.

Normalmente, sentimos na vegetação que floresce ou que murcha uma raiz que demonstra nas diferentes reacções à mudança das estações como está viva.

Veneza, porém, é estranha a isto a partir do seu próprio íntimo, o verde dos seus escassos jardins, que parece estar enraizado, ou não estar enraizado, algures na pedra ou no ar, é como que imune à mudança.

Como se todas as coisas tivessem reunido toda a beleza que são capazes de dar à superfície e, depois, se tivessem retirado desta, de modo que agora é como se estivesse petrificada que ela guarda essa beleza, a qual já não acompanha a vivacidade e o desenvolvimento do verdadeiro ser.

Não existe provavelmente outra cidade cuja vida decorra tão integralmente à mesma velocidade.

Não há animais de tiro ou veículos a arrastar o olhar que os acompanha em velocidades variadas, as gôndolas têm absolutamente a velocidade e o ritmo de pessoas a caminhar.

E é esta a verdadeira causa do carácter "sonhador" de Veneza desde sempre sentido. 
A realidade está constantemente a sobressaltar-nos; a alma, abandonada a si própria ou a uma influência persistente, permaneceria num certo equilíbrio, e só a variação das suas sensações aponta para um ser exterior que provoca estas interrupções da sua posição de repouso.

Por isso, as impressões sempre uniformes hipnotizam-nos, um ritmo a que estamos expostos em permanência leva-nos ao estado sonolento do irreal.

A monotonia de todos os ritmos venezianos priva-nos das sacudidelas e dos estímulos que são necessários ao sentimento de plena realidade e aproxima-nos do sonho, em que a aparência das coisas nos rodeia sem as próprias coisas.

De acordo com as suas próprias leis, a alma, presa no ritmo desta cidade, produz em si o mesmo estado de espírito que a forma estética dela oferece na forma da objectividade: como se só as camadas superiores da alma, que se limitam a captar reflexos, a fruir passivamente, respirassem ainda, enquanto a sua realidade plena permanece à margem como que num sonho indolente.

Mas na medida em que estes conteúdos, separados das substâncias e emoções da verdadeira vida, constituem aqui, apesar disso, a nossa vida, esta torna-se, a partir de dentro, participante da mentira de Veneza.

Porque o que é trágico em Veneza, o que a transforma no símbolo de uma ordem muito especial das nossas formas de compreender o mundo, é o facto de a superfície que se destacou do seu fundamento, de a aparência em que já não vive um ser, se fazer passar, apesar disso, por algo completo e substancial, pelo conteúdo de uma vida verdadeiramente apta a ser vivida.

Florença faz-nos pressentir que as mesmas forças que deram forma ao seu chão e fizeram brotar as suas flores e árvores também geraram, por via da mão do artista, o Paraíso de Orcagna e a Primavera de Botticelli, a fachada de S. Miniato e o Campanile de Giotto.

Por isso, a vida espiritual que estabelecia a ligação entre aquele nebuloso chão primevo e estas formas cristalinas do espírito poderá ter desaparecido há muito e dela apenas ter restado uma aparência estética - apesar disso, esta não é uma mentira porque nela se mantém presente o ser que lhe indica o lugar que lhe pertence.

Só onde uma aparência à qual nunca correspondeu um ser e que viu morrer mesmo o ser que se lhe opunha presume oferecer uma vida e uma totalidade é que ela representa a mentira em estado puro e que a ambiguidade da vida confluiu nela confundindo-se com o seu próprio corpo.

É ambíguo o carácter destas praças que, sem carros, com o seu fechamento estreito e simétrico, tomam a aparência de quartos, é ambíguo, nas ruas estreitas, o inevitável comprimir-se 
e tocar-se das pessoas, que dá a esta vida a aparência de uma familiaridade e um "aconchego" a que falta o mínimo resquício de alma; é ambígua a vida dupla da cidade, umas vezes na forma do conjunto das ruas, outras, na forma do conjunto dos canais, de modo que ela não pertence nem à terra nem à água - pelo contrário, cada uma delas aparece como o manto proteico por sob o qual a outra seduz de cada vez como o verdadeiro corpo; são ambíguos os canais pequenos e escuros, cuja água se agita e corre tão inquieta - mas sem que possa reconhecer-se a direcção em que corre, ela que está sempre em movimento, mas sem que esse movimento tenha um destino.

O facto de a nossa vida verdadeiramente não ser mais do que a fachada por trás da qual aguarda a única coisa certa, a morte - este é o motivo último que explica que a nossa vida, como diz Schopenhauer, seja "inteiramente ambígua"; pois quando a aparência não cresce a partir de uma única raiz, cuja seiva a mantém numa direcção determinada, ela fica exposta à interpretação do arbítrio.

Só à arte é dado, nos seus momentos mais felizes, acolher um ser na aparência e oferecer este ao mesmo tempo que se oferece a si própria.

E por isso é que a arte só é perfeita e só está para além do artifício quando é mais do que arte.

Assim é Florença, que proporciona à alma a segurança magnificamente unívoca de uma terra natal.

Veneza, porém, possui a beleza ambígua da aventura que flutua sem raízes pela vida, como uma flor arrancada à deriva no mar, e o facto de ela ter sido e ter permanecido a cidade clássica da aventure não é senão a materialização do destino final da sua imagem de conjunto: não poder ser para a nossa alma uma terra natal, mas tão-somente uma aventura. 


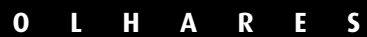

IMPRENSA DA UNIVERSIDADE DE COIMBRA

COIMBRA UNIVERSITY PRESS 